\title{
Drivers of flood risk change in residential areas
}

\author{
F. Elmer ${ }^{1,2}$, J. Hoymann ${ }^{3}$, D. Düthmann ${ }^{2,4}$, S. Vorogushyn ${ }^{4}$, and H. Kreibich ${ }^{4}$ \\ ${ }^{1}$ Deutsches GeoForschungsZentrum GFZ, Telegrafenberg, Wissenschaftliche Infrastruktur, 14473 Potsdam, Germany \\ ${ }^{2}$ Center for Disaster Management and Risk Reduction Technology CEDIM, Karlsruher Institut für Technologie, Hertzstr. 16, \\ Geb. 6.42, 76187 Karlsruhe, Germany \\ ${ }^{3}$ Bundesinstitut für Bau- Stadt- und Raumforschung (BBSR), Im Bundesamt für Bauwesen und Raumordnung (BBR), \\ I5 Verkehr und Umwelt, Deichmanns Aue 31-37, 53179 Bonn, Germany \\ ${ }^{4}$ Deutsches GeoForschungsZentrum GFZ, Telegrafenberg, Sektion 5.4, 14473 Potsdam, Germany \\ Correspondence to: F. Elmer (elmer@gfz-potsdam.de)
}

Received: 2 September 2011 - Revised: 16 February 2012 - Accepted: 5 April 2012 - Published: 23 May 2012

\begin{abstract}
The observed increase of direct flood damage over the last decades may be caused by changes in the meteorological drivers of floods, or by changing land-use patterns and socio-economic developments. It is still widely unknown to which extent these factors will contribute to future flood risk changes.
\end{abstract}

We survey the change of flood risk in terms of expected annual damage for residential buildings in the lower part of the Mulde River basin (Vereinigte Mulde) between 1990 and 2020 in 10-yr time steps based on measurements and model projections. For this purpose we consider the complete risk chain from climate impact via hydrological and hydraulic modelling to damage and risk estimation. We analyse what drives the changes in flood risk and quantify the contributions of these drivers: flood hazard change due to climate change, land-use change and changes in building values.

We estimate flood risk and building losses based on constant values and based on effective (inflation adjusted) values separately. For constant values, estimated building losses for the most extreme inundation scenario amount to more than 360 million $€$ for all time steps. Based on effective values, damage estimates for the same inundation scenario decrease from 478 million $€$ in 1990 to 361 million $€$ in 2000 and 348 million $€$ in 2020 (maximum land-use scenario). Using constant values, flood risk is $111 \%$ (effective values: $146 \%$ ) of the 2000 estimate in 1990 and $121 \%$ (effective values: $115 \%$ ) of the 2000 estimate for the maximum land-use scenario in 2020. The quantification of driver contributions reveals that land-use change in the form of urban sprawl in endangered areas is the main driver of flood risk in the study area. Climate induced flood hazard change is important but not a dominant factor of risk change in the study area. With the historical exception of the economic effects in Eastern Germany following the German reunification, value developments only have minor influence on the development of flood risk.

\section{Introduction}

Losses from natural disasters have dramatically increased during the last few decades, and in terms of economic losses, floods have been the most severe event type (Munich Re, 1997, 2004). It is expected that flood risk will continue to rise in consequence of a combination of climate change (e.g. Kundzewicz et al., 2005) and an increase in vulnerability, e.g. due to increasing flood plain occupancy, value increase in endangered areas and changes in the terrestrial system, e.g. land cover changes and river regulation.

While the concept of climate change and global warming is widely accepted, the impacts on the regional and local scales can be very different and require a closer look. In terms of the increase in flood hazard, recent studies show a mixed picture in Germany and Central Europe. Large scale flood regimes are affected differently by climate induced meteorological changes (Hattermann, 2005). Petrow et al. (2009a, b) analysed the frequency and magnitude of extreme flood events in Germany over the course of $52 \mathrm{yr}$ (1951 to 2002). Positive trends (increase in magnitude and frequency of extreme discharges) could be found for the western, southern and central parts of Germany, while in the northeast changes in flood behaviour are small and not field 
significant. Generally, changes in the winter season exceed those in the summer. Other studies (Merz and Blöschl, 2009; Blöschl and Montanari, 2010; Veijalainen et al., 2010, Prudhomme et al., 2010) discuss whether there is any significant increase in flood hazard at all.

Besides the impact of hazard change on flood risk, the accumulation of values in flood prone areas and changes in values are discussed as possible drivers for changes in risk. Indeed, the analysis of Barredo (2009) suggests that the past changes in economic losses are related to the latter two factors.

Land-use changes for the Elbe basin were analysed and land-use projections were developed within the GLOWAElbe framework ("Global Change Impacts on the Water Cycle in the Elbe River Basin", a German governmental funded research initiative) described by Hoymann (2010, 2011). These projections are used to analyse future risk developments within this study. Approaches integrating both landuse changes and flood hazard changes were undertaken by Archer et al. (2010), Orr and Carling (2006), De Roo et al. (2003) and Bronstert et al. (2002) and analyse the impact of land-use changes on flood discharges. A broad approach on the national scale that considers a range of flood risk drivers for fluvial and coastal floods was presented by Hall et al. (2003) for England and Wales. It combines quantified risk analysis and also resorts to expert appraisal for judging the influence of risk drivers to project future (2030 to 2100) flood risk under different scenario conditions.

Recent studies by Feyen et al. (2009), Bouwer et al. (2010) and te Linde et al. (2011) focus on both the impact of landuse changes and climate induced flood hazard changes and their influence on flood damage. Te Linde et al. (2011) investigated possible flood risk scenarios along the entire Rhine River and quantified the contribution of climate change and land-use changes to overall risk change. They considered two climate change scenarios, two land-use scenarios and the official flood protection targets of seven sections of the Rhine. An extreme inundation scenario was taken from the International Commission for the Protection of the Rhine "Rhine Atlas" (ICPR, 2001) to calculate potential damage and damage expectations for a number of land-use classes. Their analyses revealed a huge increase in expected annual damage (EAD) ranging from $54 \%$ to $230 \%$ in 2030 compared to 2000 , depending on the climate change and land-use scenario. Approximately three-quarters of the increase were attributed to the climate change. These findings diverge from the assessments of the observed trends in economic losses in Europe, where no climate signal was detected (Barredo, 2009). Merz et al. (2010a) identify and describe the types and magnitude of changes in flood risk in Europe and the associated increase of uncertainty and analyse and discuss the implications for flood risk management.

To our best knowledge, no research has so far tried to close the whole risk chain from climate impact via hydrological and hydraulic modelling to damage and risk estimation while also considering building stock and value developments. Our first objective is to set up this model chain as the example of a meso-scale catchment in Germany. Second, we model the development of potential damage in the study area over time and transfer this damage to risk estimates. Third, we analyse which drivers cause the change of flood risk and quantify the contributions of these drivers: flood hazard change (change of the probability of events of a certain magnitude), landuse change (changes in residential area and the associated building stock composition) and changes in building values in terms of reconstruction costs for potentially affected residential buildings.

The paper has the following structure: Sect. 2 presents the study area, followed by Sect. 3 "Data and methods" that first gives an overview of the approach and then presents the data and models used in each step of the risk chain (climate and meteorology - hydrology - hydraulics - land-use and building stock - building values - damage - risk). Intermediate results from all chain links, the results of the damage estimates and risk analysis, and the quantification of the aforementioned influences to overall flood risk are presented and discussed in Sect. 4. Finally, we conclude our analysis and provide an outlook and recommendations for future research.

\section{Study area}

The study area comprises the lower part of the Mulde catchment downstream of the confluence of Zwickauer Mulde and Freiberger Mulde (Fig. 1). The Mulde River is a sinistral tributary to the Elbe River with a total length of $290 \mathrm{~km}$ (including Zwickauer Mulde) and a length of $124 \mathrm{~km}$ from the confluence of the main frontal flows (Zwickauer Mulde and Freiberger Mulde) to the Elbe River, the Vereinigte Mulde reach. All main frontal flows originate in the Ore Mountains. The Vereinigte Mulde River is located in the North German Plain and its catchment area is $2054 \mathrm{~km}^{2}$. Cities located along the Vereinigte Mulde River are Dessau, Bitterfeld, Wolfen, Bad Düben, Wurzen and Eilenburg.

The study area contains 35 municipalities in their administrative borders of the year 2000. It comprises those municipalities which are partly inundated from an extreme event with a return period at gauge Golzern 1 of $T=1000 \mathrm{yr}$ (probability as of 2000), corresponding to the maximum inundation scenario (S9) generated for this research. Municipalities that are located in the catchment but are not affected by the maximum scenario (approximately $1000 \mathrm{~km}^{2}$ ) are excluded. The total area of the affected municipalities and thus the study area is $1063 \mathrm{~km}^{2}$, of which about $8.4 \%$ were covered by residential areas in 2000 (Corine Land Cover, 2000; Keil et al., 2005). Because of constraints in hydraulic modelling, no inundation scenarios could be created for the river reach from the gauge at Dessau-Muldebrücke to the Elbe River. This results in moderately underestimating damage and risk for the city of Dessau. 


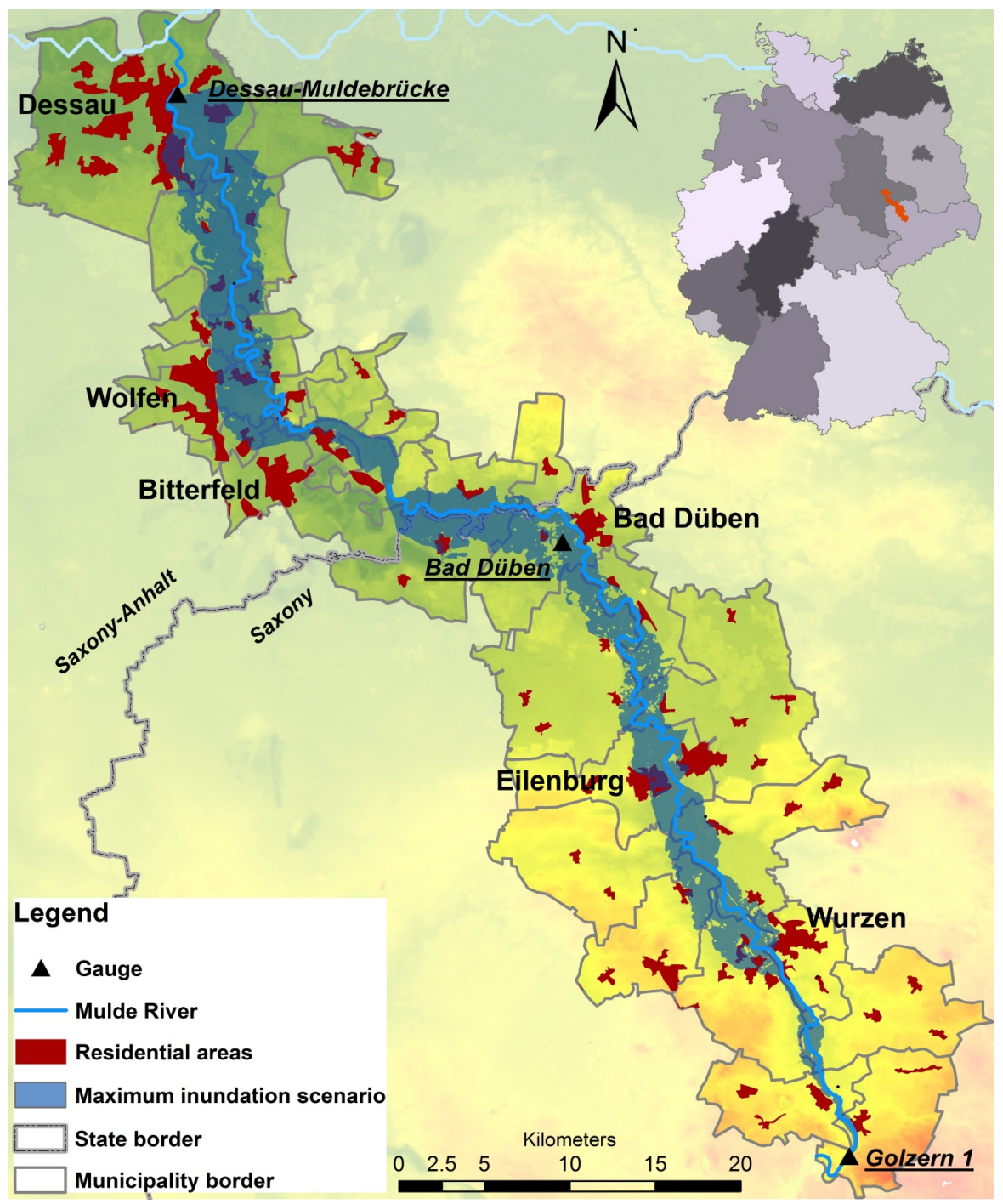

Fig. 1. Study area "Vereinigte Mulde" (municipality borders as of 2000).

The region has undergone major socioeconomic changes since 1990. Due to the economic problems after the reunification of Germany, the population decreased rapidly while, in the same time span, residential areas spread due to changes in the building of new residential structures. Unrestrictive policies and changes in demand resulted in single-family homes being the huge majority of houses built after 1990 . This fact, combined with an increase of living space per capita, led to land consuming settlement patterns despite the population decrease. The land-use and building stock projections take this very special development into account.

Flooding of the Mulde River is a common natural hazard in the region. The August 2002 flood in the Elbe basin also affected the study area severely (Haase et al., 2003; Engel, 2004; BfG, 2006; LuG, 2009), causing many dike breaches and damage at other flood protection and river management structures and massive losses; e.g. residential damage in the city of Eilenburg amounted to 77.12 million $€$ (Apel et al., 2009).

In terms of climate induced flood hazard changes, the Mulde area is located in a transitional zone. The study by Beurton and Thieken (2009) on the regionalisation of flood regimes in Germany indicates that the study area cannot be directly assigned to one of the three major flood regime regions in Germany. Neither can it be regarded as a region with significant trends in flood frequency and magnitude (Petrow and Merz, 2009).

\section{Data and methods}

The central idea of our approach is to provide analyses on flood risk change and driver contribution based on a complete 


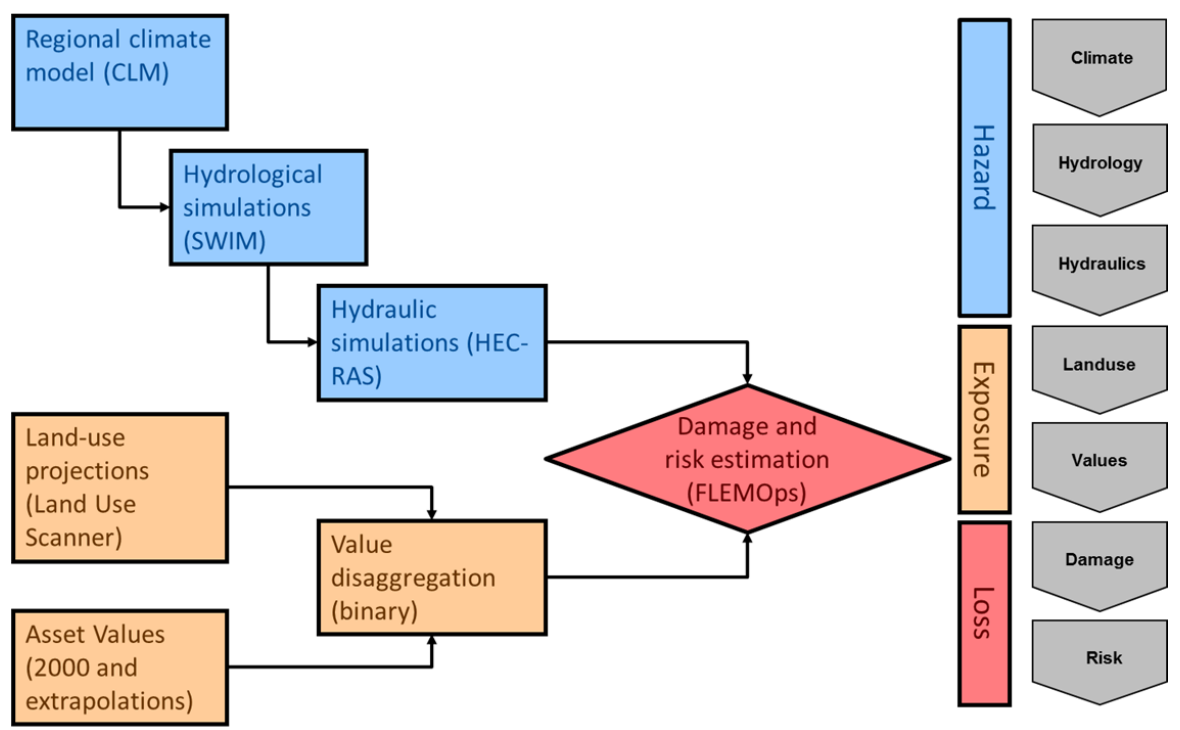

Fig. 2. "Flood Risk Chain" - Chain links and models.

risk chain. This was realized in a model cascade, which accounts for all risk chain links and considers scenarios of climate change, land-use change and asset value development (Fig. 2).

Risk was calculated in terms of expected annual damage (EAD) for 1990, 2000, 2010 and 2020 using sets of damage estimates with consistent scenario assumptions. Changing one parameter at a time, the contribution of flood risk drivers (flood hazard, land-use and building stock, building values) to overall risk change was quantified.

\subsection{Quantification of the flood hazard}

We defined the flood hazard for four points in time in ten year intervals based on the discharge time series for the preceding $50 \mathrm{yr}$ (e.g. the flood hazard in 1990 is based on the discharge time series 1941 to 1990, see Fig. 3). Discharge data provided the input for inundation modelling and they were also used in the extreme value statistics to calculate flood probabilities. We used daily discharge data for full hydrological years (1st of November to 31st of October). Measured discharge data were used for the time period 1941 to 2000, and simulated discharge data, generated by a hydrological model with climate input based on a future climate scenario, were applied for the time period 2001 to 2020.

Two discharge gauges were used in this study (Fig. 1). Golzern 1, the most upstream gauge in the study area, is used as the reference gauge and as interface to the hydraulic modelling. Uninterrupted discharge measurements are available for 1935, onwards. For the Bad Düben gauge, daily discharge data are available for 1961, onwards.

Discharges corresponding to nine defined return periods $(2,5,10,20,50,100,200,500,1000 \mathrm{yr})$ were computed based on extreme value statistics for Golzern 1 for 2000 . These peak flows were used in a hydraulic model to create a set of inundation scenarios. The discharges for the Bad Düben gauge were extracted from these inundation scenarios and return periods were calculated for the Bad Düben based on discharge time series (measured and modelled).

To project the risk changes associated with climate change according to the IPCC A1B emission scenario (A1: very rapid economic growth, global population peaks in midcentury, new technologies; B: balanced use of energy sources, IPCC, 2000), we applied climate data which have been dynamically downscaled from the ECHAM5 General Circulation Model (GCM) using the regional climate model (RCM) COSMO-CLM with a $0.2^{\circ}$ horizontal resolution, provided by Deutsches Klimarechenzentrum (German Climate Computing Center - DKRZ 2006, 2007). The downscaled climate data were used to drive the regional hydrological model SWIM, which computes the discharge values at the reference gauge Golzern 1.

SWIM (Krysanova, Wechsung et al., 2000, Krysanova, Müller-Wohlfeil et al., 1998) is a process based semidistributed hydrological model. For this study it was set up for the Mulde catchment using the following spatial input data: a digital elevation model (DEM; 25 m-DEM from BKG within Germany), land cover data (CLC) and soil data (BUEK, 1000). Observed climate time series based on the DWD station network (data set prepared by PIK using 264 climate stations, Österle et al., 2006) were used as input for model calibration and validation. The time series of meteorological data were interpolated onto a $1 \mathrm{~km}^{2}$ grid, and aggregated to subcatchment average mean values using universal kriging with elevation for temperature data and the inverse distance weighting method for precipitation, humidity 


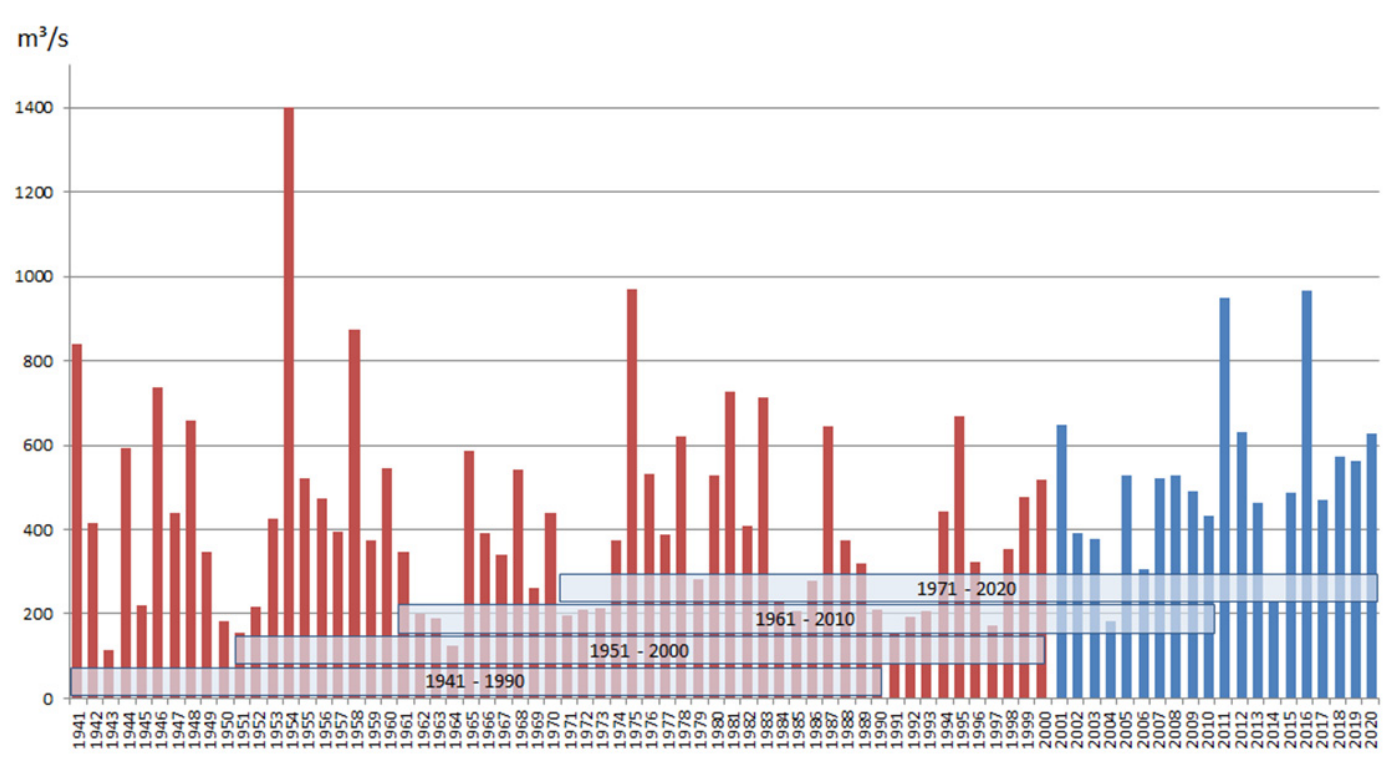

a discharge measurements $\quad \square$ dischargeSWIM A1B moving window time periods

Fig. 3. Golzern 1 - Annual maximum series (AMS) of mean daily discharge 1941 to 2020 and shifting windows for flood hazard analysis.

and radiation. Daily precipitation data were corrected for undercatch errors, depending on wind speed and the aggregation state of the precipitation (Yang et al., 1999). The SWIM model was calibrated automatically using the SCE-UA algorithm (Duan et al., 1992, 1993, 1994) over a period of five years from 1991 to 1995 with one year for model initialization, and the results were further fine-tuned manually. For the calibration period the Nash-Sutcliffe efficiency (Nash and Sutcliffe, 1970) at Golzern is 0.75 with a bias of $2.4 \%$; for the validation period (1961 to 2000 excluding 1991 to 1995 ) these values are 0.83 and $-2.3 \%$. The performance of the model was evaluated visually with respect to daily flows, average and maximum monthly flow regimes, average and maximum annual discharges and flow exceedance curves at more than 20 gauges within the Mulde catchment, but the results cannot be shown here.

In order to generate discharge data for the scenario period 2001 to 2020, the hydrological model was run using the RCM data. These data were also mapped to subcatchments and a bias correction using quantile mapping (Piani et al., 2010) was applied to all climate variables based on the measured climate data interpolated to subcatchments.

To characterize the flood hazard, we computed the extreme value statistics at gauges along the study reach. A set of probability distribution functions was fitted to four 50 -yr time series (1941-1990 till 1971-2020), as shown in Fig. 3 for gauge Golzern 1.

The resulting return periods are associated with the last year of each time slice. Since several probability distribution functions may satisfactorily describe the data variabil- ity, we based our assessment on a composite distribution function approach (Wood and Rodríguez-Iturbe, 1975). The composite function resulted from weighting the distribution functions based on likelihood weights. Flood hazard was expressed as recurrence interval. The probability of each discharge was calculated for 1990, 2000, 2010 and 2020 based on $50 \mathrm{yr}$ discharge time series. Recurrence intervals provided the input for modelling inundation scenarios and were considered in the damage model as one parameter for loss estimation. Finally, they were taken into account to determine flood risk in terms of EAD.

The hydraulic simulations were carried out using the HECRAS (USACE, 2010) model setup for the reach between gauges Golzern 1 and Dessau-Muldebrücke. From Golzern 1 to Bad Düben, the model was based on detailed cross-sections provided by LTV (Landestalsperrenverwaltung) Sachsen. In the downstream part of the reach, the cross-sections were extracted from the DEM with $25 \times 25 \mathrm{~m}$ horizontal resolution.

The model was calibrated in a steady-state using the flow boundary conditions at Golzern 1, Bad Düben and Priorau gauges and normal depth as the downstream boundary. Modelled water depths from the steady-state run were interpolated and intersected with the DEM25. The resulting water depths at several points were compared with the high water marks and inundation areas from the 2002 flood compiled by DLR (Deutsches Zentrum für Luft- und Raumfahrt) and BKG (Bundesamt für Kartografie und Geodäsie) (Fig. 4). Manning's roughness coefficients were manually adjusted to reduce the RMSE between measured and simulated water 


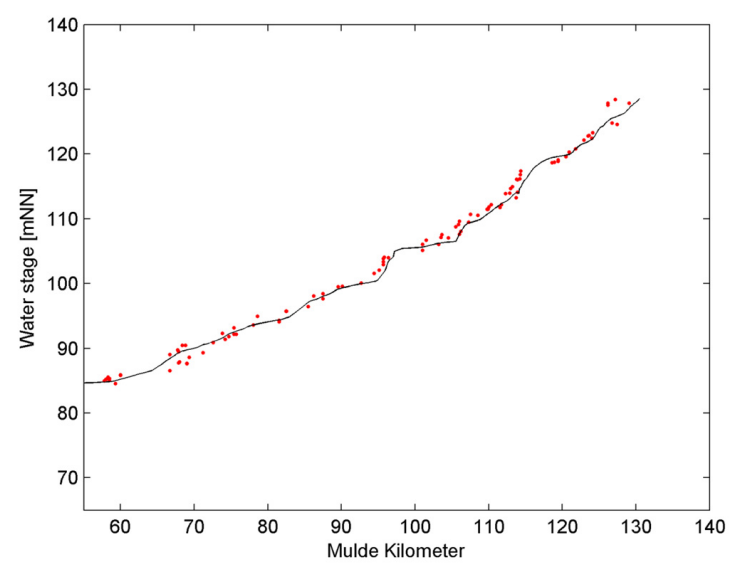

Fig. 4. Water stage profiles along the Mulde - Simulation results from steady-state run (black line) vs. observed values (red dots).

stages and to achieve the best estimations of flood areas, characterised by flood area indices (F1, F2, F3) which are defined as follows:

$$
\begin{aligned}
& \mathrm{F} 1=\mathrm{M} 1 \mathrm{D} 1 /(\mathrm{M} 1 \mathrm{D} 1+\mathrm{M} 1 \mathrm{D} 0+\mathrm{M} 0 \mathrm{D} 1) \\
& \mathrm{F} 2=(\mathrm{M} 1 \mathrm{D} 1-\mathrm{M} 1 \mathrm{D} 0) /(\mathrm{M} 1 \mathrm{D} 1+\mathrm{M} 1 \mathrm{D} 0+\mathrm{M} 0 \mathrm{D} 1) \\
& \mathrm{F} 3=(\mathrm{M} 1 \mathrm{D} 1-\mathrm{M} 0 \mathrm{D} 1) /(\mathrm{M} 1 \mathrm{D} 1+\mathrm{M} 1 \mathrm{D} 0+\mathrm{M} 0 \mathrm{D} 1)
\end{aligned}
$$

M0D0 denotes the raster cells modelled as dry and observed dry, M0D1 denotes cells modelled as dry and observed as wet, M1D0 denotes cells modelled as wet and observed dry, and M1D1 denotes cells modelled as wet and observed wet.

From 118 high-water marks, 70 points are inundated in the modelling results and 48 are simulated as dry. RMSE for water depths after interpolation and intersection with the DGM25 amounts to $0.66 \mathrm{~m}$.

Flood area indices were computed for two different model domains, which used different roughness parameterisation, and finally for the whole domain:

- The whole modelling domain from gauge Golzern 1 to Dessau-Muldebrücke

- From Golzern 1 to the border with Saxony-Anhalt (Saxony)

- From the border of Saxony to the gauge DessauMuldebrücke (Saxony-Anhalt)

The results are summarised in Table 1.

The results for the whole domain can be regarded as satisfactory and compare well with similar studies (Horritt and Bates, 2001, 2002). The model performance for the Saxon part of the reach appeared to be better than the part in
Table 1. Performance statistics of the inundation model in terms of flood area indices (FAI).

\begin{tabular}{llll}
\hline FAI/Domain & Whole domain & Saxony & Saxony-Anhalt \\
\hline F1 & 0.77 & 0.85 & 0.68 \\
F2 & 0.61 & 0.8 & 0.38 \\
F3 & 0.7 & 0.75 & 0.65 \\
\hline
\end{tabular}

Saxony-Anhalt. Manning's roughness values between 0.04 and $0.16 \mathrm{~m}^{1} 3^{s}-1$ were achieved in the calibration process.

Inundation scenarios were derived for return periods of $2,5,10,20,50,100,200,500$ and $1000 \mathrm{yr}$ based on extreme value statistics at Golzern 1 gauge. A typical flood hydrograph was derived from a cluster analysis of the historical flood hydrographs based on the approach of Apel et al. (2006) and upscaled to the selected return periods. The unsteady scenario runs assumed the normal depth as downstream boundary condition. Steady flows corresponding to the initial discharges of the flood hydrographs were used as initial condition. The maximum simulated water stages were intersected with the DEM25 using the HEC-GeoRAS tool to obtain inundation depths.

Flood protection measures are not taken into account due to the lack of consistent information on such structures.

\subsection{Exposure}

Damage modelling for residential buildings requires information on spatial distribution specific value as well as quality of the building stock.

Our survey used land-use data from CLC1990 and CLC2000 that were published in 2005 (a revised version of CLC1990 is included in the CLC2000 data set). These data were derived from Landsat satellite imagery and provide a consistent land-use classification for Europe (for details, see Keil et al., 2005).

We reclassified CLC data into two classes - residential and non-residential - aggregating class 111 (Continuous urban fabric) and 112 (Discontinuous urban fabric) to residential land-use. All other classes were aggregated to nonresidential land-use as we did not assign any residential building values to these classes. Land-use projections for 2020 were taken from Hoymann $(2010,2011)$ who developed land-use scenarios for the entire Elbe basin. The 2010 projections are an interpolation of year 2000 input data derived from CLC2000 land-use information and year 2020 projections. Hoymann based the projections on calculations of the demand for residential land-use. The allocation of residential land-use was then modelled with the GISbased Land Use Scanner (LUS) model (Hilferink and Rietveld, 1999; Schotten et al., 2001; Hoymann, 2008) that allocates land-use changes to grid cells using regional claim sets (land-use demand) and suitability maps (current landuse, physical suitability, distance relations, regional spatial 
planning, nature protection areas). The LUS application for the Elbe basin assigns land-uses to a $250 \mathrm{~m}$-grid. For this survey we used a derivate of the land-use change scenarios which provide the proportion of expected residential land-use per grid cell. The different land-use change scenarios were based on the IPCC emission scenario storylines A1 (rapid economic growth) and B2 (local environmental sustainability) (IPCC 2000). These global storylines were transferred to the regional developments in the Elbe basin. To consider regional influences, both trajectories were combined with two different land-use policies: maintaining the current (weak) land-use policy $\left({ }^{0}\right)$ and restrictive land-use policy $\left(^{+}\right.$) (Hoymann, 2011, details in Hartje et al., 2008). Four residential land-use development scenarios were used in this survey for 2010 and 2020, respectively:

\section{$\mathrm{A} 1^{0}$ : Globalisation with weak spatial planning policy}

\section{$\mathrm{A} 1^{+}$: Globalisation with very restrictive spatial planning policy}

\section{$B 2^{0}$ : Differentiation with weak spatial planning policy}

\section{$\mathrm{B} 2^{+}$: Differentiation with very restrictive spatial planning policy}

To make land-uses comparable for the whole research period, some modifications were conducted on the CLC data: CLC1990 and CLC2000 polygons are intersected with the $250 \mathrm{~m}$-grid from the LUS projections. The proportion of residential land-use in each cell was identified and assigned as cell value to the respective residential land-use grids for 1990 and 2000 .

A complete set of building values on the municipality level was created within the CEDIM framework by Kleist et al. (2006) for the year 2000. The cost approach was selected to value buildings and consequently, values were given as reconstruction costs, i.e. the market price of the construction works for restoring a damaged building.

The values were disaggregated, i.e. distributed to the respective land-use units. Thieken et al. (2006) and Wünsch et al. (2009) applied and tested various disaggregation approaches and analysed the influence of these disaggregation schemes on the uncertainty of flood damage estimations. They commended the application of a binary disaggregation approach when using CLC data. The appropriateness of this disaggregation approach was confirmed by our own tests using it for damage estimations in the Saxon parts of the Mulde basin.

The total value of residential buildings for each municipality was taken from Kleist et al. (2006) and this figure was divided by the residential area $\left(\mathrm{m}^{2}\right)$ as taken from the land-use information for the year 2000 to get a specific value per square meter for residential land-use only. These values were then multiplied with the proportion of residential landuse per grid cell resulting in a monetary building stock value for each grid cell. The latter step was done for the 1990 and 2000 land-use information and all 2010 and 2020 land-use scenarios. Damage and risk estimations are comparable for different points of time because the building values per $\mathrm{m}^{2}$ are constant and, accordingly, the influence of inflation is externalised.

To analyse the influence of building value changes with time, values in terms of reconstruction costs were time adjusted by using official indexed construction prices (Baupreisindex - BPI, DESTATIS, 2010b) for 1990 and 2010 and a linear extrapolation of this index for 2020. The BPI gives the development of construction prices relative to a reference year (for this study the year 2000) and can be interpreted as the inflation of building construction prices. The inherent changes in building values are identified by the inflation-adjustment of time adjusted values with indexed consumer prices (Verbraucherpreisindex - VPI, DESTATIS 2012). The BPI is based on the prices for construction works. These construction works contribute only a small degree to the calculation of the VPI and hence this influence was ignored for our calculations. These adjusted values will be referred to as "effective values" or "effective value changes" in contrast to the "constant values" in the preceding paragraph.

Municipal building stock characteristics were originally derived from a Germany-wide data set for the year 2000 created by INFAS Geodaten in combination with official statistical data about building type and quality. Average building quality per municipality ( 5 classes, aggregated for use in the applied damage model to only two classes: high quality and medium/low quality, see Thieken et al., 2008) and the composition of residential building stock in terms of percentages of single-family houses, semi-detached/detached and multifamily houses is provided on the municipality level for 2000 . Since only a few municipalities in Germany (and none in the study area) had a high average building quality, we assumed that the class affiliation (medium to low average building quality) remains constant for all municipalities in the study area, all points in time and all scenarios.

The composition of residential building stock in Germany in terms of building types was retained by applying a clustercentre approach (Thieken et al., 2008) based on the share of the three building types in 2000. This resulted in five cluster centres to which all municipalities were assigned. To calculate the building stock composition for the study area in 1990, 2010 and 2020, a linear extrapolation following official statistics about builds and demolitions for each building type at the district level (Landkreise and Kreisfreie Städte) from 1995 to 2004 (DESTATIS 2010a) was used. The linear trend was applied to the reference data from Thieken et al. (2008) on the municipality level for 2000 and extended back to 1990 and forward to 2010 and 2020. We assumed uniform trend behaviour for all municipalities within one district. 
The building stock compositions for each municipality and point in time are related to the year 2000 cluster-centres. Cluster "borders" were constructed in a de Finetti diagram (Tri-Plot freeware by Graham and Midgley, 2000) and the direction and magnitude of the changes in building stock composition for each municipality are given.

\subsection{Flood damage and flood risk}

We used a modified version of the multi-criteria Flood Loss Estimation Model for the private sector (i.e. residential buildings) FLEMOps (Thieken et al., 2008; Elmer et al., 2010) to estimate flood damage to residential buildings. A number of stage damage functions exist (see, e.g. Merz et al., $2010 \mathrm{~b}$ for a review) and some models provide a number of functions to account for, e.g. different building types or loss sectors, but FLEMOps is the only validated empirical multi-factor damage model for Germany. Contrary to simple stage-damage functions, FLEMOps uses additional parameters such as building type, building quality and flood probability in the damage calculation procedure. The damage modelling process on the meso-scale is given in Fig. 5.

FLEMOps is derived from empirical damage data of 2158 residential loss cases in Germany acquired after floods in 2002, 2005 and 2006 (Thieken et al., 2005; Kreibich and Thieken, 2008). The latest model version FLEMOps+r considers water level, building type and building quality and additionally the effects of flood probability (in terms of recurrence interval), precautionary measures and water contamination (Eq. 1) and is presented and validated in Elmer et al. (2010). However, in this study we ignored the influence of the latter two factors since no reliable methodology is available to model scenarios for precaution and contamination. A plausibility check for this version was undertaken for four Saxon municipalities in the Mulde catchment with more than 300 damaged residential buildings in the 2002 flood event (Eilenburg and Bennewitz in the study area, Grimma just south of the gauge at Golzern and Döbeln at the Freiberger Mulde River). Official damage data were provided by Sächsische Aufbaubank (SAB - Saxon Bank for Development) for the 2002 event. Results from the comparison with modelled damage using the 2002 flood extent information are very satisfactory: an underestimation of just $12 \%$ with estimates for the single municipalities ranging from $-32 \%$ to $+12 \%$ of the official residential damage.

Equation (1) was used to estimate relative building damage

$D_{\mathrm{E}}$ for each scenario.

$D_{\mathrm{E}_{j}}=\left(\frac{\Sigma^{n_{j}} D_{h_{j}}}{n_{h_{j}}} \times \frac{\Sigma^{n_{j}} D_{t q_{j}}}{n_{t q_{j}}} \times \frac{n}{\Sigma^{1_{n}}}\right) \times \Sigma \frac{D_{p c T_{j}}}{D_{p c T_{j}}} \times \frac{1}{n_{p c T_{j}}}$

Equation (1) with:

$$
j=(\text { damage }) \text { case }
$$

$D=$ relative damage (interview information)

$D_{\mathrm{E}}=$ estimated relative damage

$h=$ water level class

$t=$ building type

$q=$ building quality

$p=$ precaution index value $(=1)$

$c=$ contamination index value $(=1)$

$T=$ recurrence interval class

pc $T=$ parameter combination (precaution,

contamination and recurrence interval) class

$n=$ number of cases

EAD was used as the indicator to describe flood risk (RI). The risk was defined as the probability of an impact times the damage assigned to the magnitude of this impact. The EAD was computed by integrating the area under the risk curve, which is constructed through interpolation of the discrete flood scenarios used in this study (Eq. 2).

$\mathrm{RI}=E\{D\} \approx \sum_{i=1}^{n} D_{i}\left(\frac{P_{i}+P_{i+1}}{2}\right)\left|P_{i}-P_{i+1}\right|$

Equation (2) with:

$$
\begin{aligned}
& \mathrm{RI}=\text { risk } \\
& E\{D\}=\text { damage expectation } \\
& i=\text { scenario number } \\
& n=\text { number of scenarios } \\
& D=\text { damage } \\
& D_{i}=\text { damage scenario } \\
& P=\text { probability } \\
& P_{i}=\text { scenario probability }
\end{aligned}
$$

\subsection{Quantification of risk change drivers}

For the separation and quantification of the contribution of risk influencing factors to overall risk change, the risk influencing parameters (flood hazard associated with climate change, land-use, building values) were changed one-at-atime. This resulted in three single-driver scenarios, which were compared to the reference scenario. 


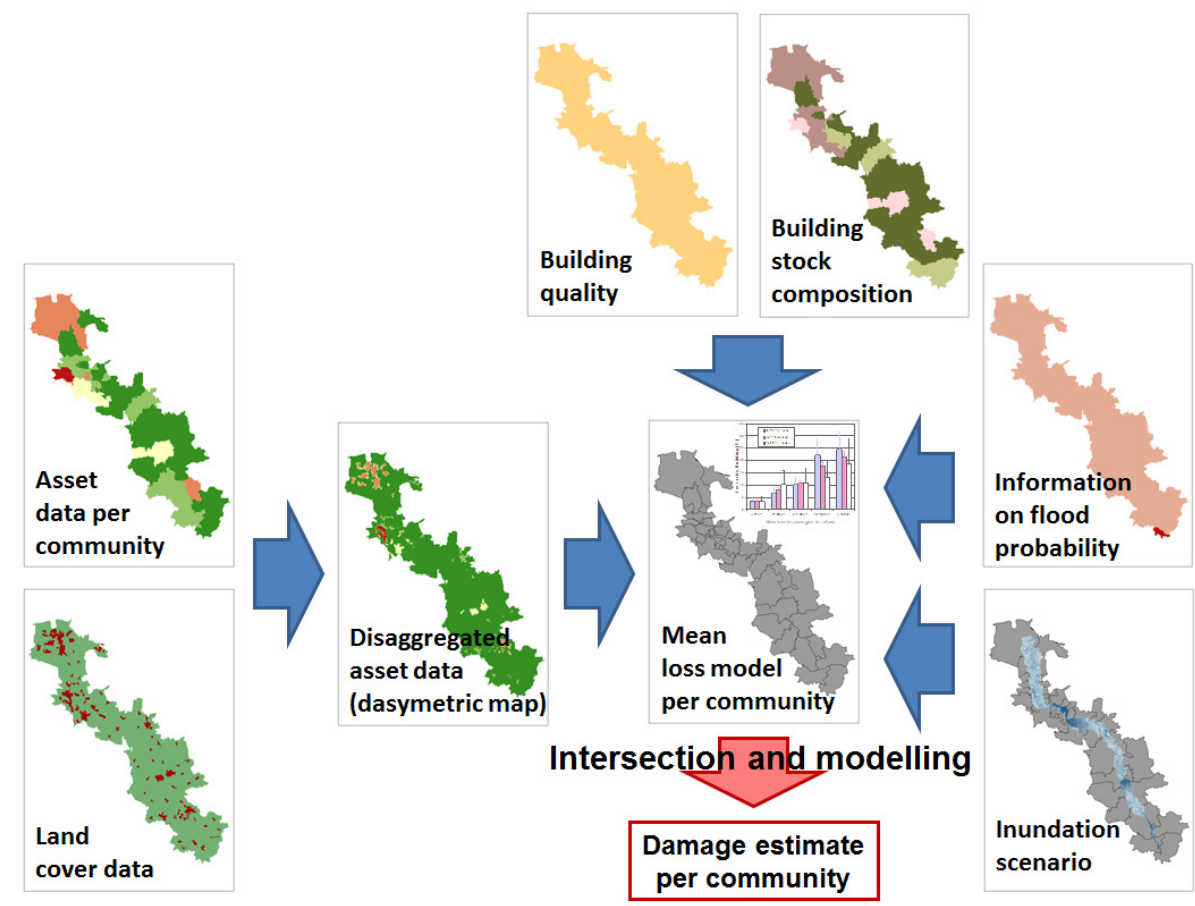

Fig. 5. Steps for meso-scale flood damage estimation with FLEMOps+r.

Table 2. Discharges and flooded area for inundation scenarios S1 to $\mathrm{S} 9$.

\begin{tabular}{llll}
\hline Scenario & \multicolumn{2}{c}{ Discharge $\left[\mathrm{m}^{3} \mathrm{~s}^{-1}\right]$} & $\begin{array}{l}\text { Inundated area }\left[\mathrm{km}^{2}\right] \\
\text { (Golzern 1 to Dessau-) } \\
\end{array}$ \\
\cline { 2 - 3 } & \multicolumn{2}{c}{ (Muldebrücke) } \\
\cline { 2 - 3 } & Golzern 1 & Bad Düben \\
\hline S1 & 352 & 324 & 127 \\
S2 & 569 & 515 & 151 \\
S3 & 725 & 659 & 162 \\
S4 & 881 & 802 & 169 \\
S5 & 1090 & 984 & 178 \\
S6 & 1251 & 1118 & 184 \\
S7 & 1418 & 1230 & 189 \\
S8 & 1650 & 1371 & 194 \\
S9 & 1842 & 1462 & 197 \\
\hline
\end{tabular}

\section{Results}

\subsection{Flood hazard}

The peak discharges of the synthetic events are presented in Table 2 and correspond to the recurrence intervals of $T=2$ (S1), 5 (S2), 10 (S3), 20 (S4), 50 (S5), 100 (S6), 200 (S7), 500 (S8), 1000 (S9) years for Golzern 1 in 2000. Recurrence intervals for other points in time vary (see Fig. 6). Modelled discharges at Bad Düben are smaller for the same scenarios because constant volumes are routed downstream and the hydrographs experience attenuation (Table 2).

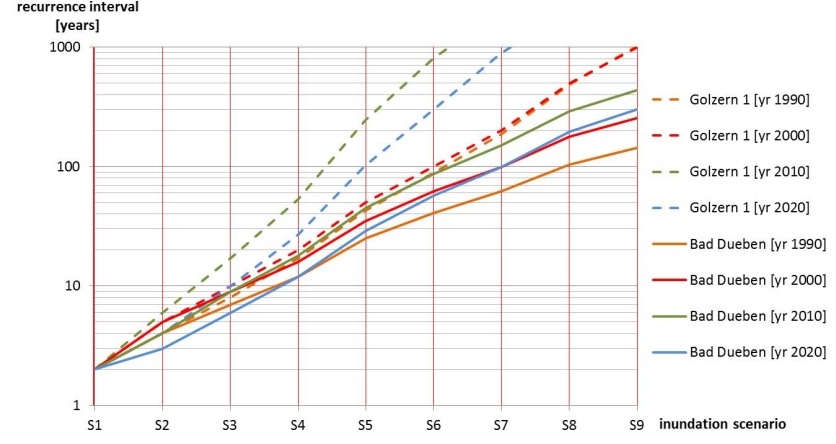

Fig. 6. Recurrence intervals for inundation scenarios at gauges Golzern 1, Bad Düben.

Figure 6 shows the changes of return periods with time for all selected scenarios. The change in time was computed in 10-yr slices as shown in Fig. 3.

The dotted lines give recurrence intervals for Golzern 1, the solid lines for Bad Düben. The calculated flood probabilities show no constant increase or decrease. For the different points in time, flood hazard ranks differently, e.g. the probability of an S2 scenario discharge at the Bad Düben gauge is highest in 2020 and lowest in 2000, while for the S9 scenario discharge the probability ranking is $1990-2000-$ 2020 - 2010. Single extreme events (e.g. events in the 1950s which are included in the hazard estimation for 1990 but not for 2000) have a dominant influence on hazard estimation and, for short periods of time, will exceed the influence 


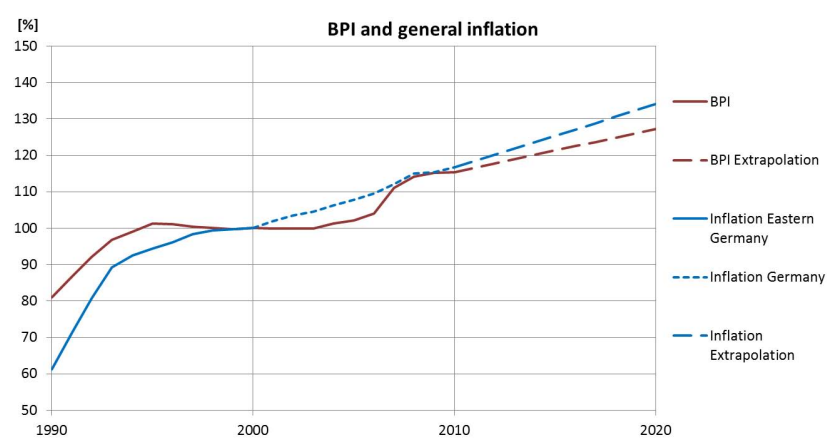

Fig. 7. Construction prices (BPI) and general inflation (VPI) - development and extrapolation to 2020 (base year 2000 =100\%).

of long term developments. Hence, it might be better to speak of (natural) climate driven hazard variability than hazard change.

Recurrence interval is used as a damage influencing factor in damage modelling. For this purpose, the recurrence intervals are classified (class 1: 1 to $9 \mathrm{yr}$; class 2: 10 to $99 \mathrm{yr}$; class 3: $>=100 \mathrm{yr}$ ), and each gauge catchment in each scenario at every point in time is assigned to one of the three classes (e.g. for 1990, the catchment area of Bad Dueben in scenario S9 is assigned to recurrence interval class 3; see Fig. 6). Between time steps there are only a few changes in recurrence interval class.

\subsection{Exposure}

Residential land-use corresponding to the CLC classes 111 and 112 covered $7.9 \%$ of the study area in 1990 and $8.4 \%$ in 2000 and shows further increase in the projections for 2010 and 2020. The share of residential land use is given in Table 3 for 1990,2000 and the extreme projections $\mathrm{B} 2^{+}$and $\mathrm{A} 1^{0}$ for 2010 and 2020.

While urban sprawl slows down after 2000, this decrease is twice as high for the "Differentiation scenario" with much stricter land use policy $\left(\mathrm{B}^{+}\right)$than for the "Globalisation scenario" with weak spatial planning policy $\left(\mathrm{A} 1^{0}\right)$.

Effective building values are adjusted for the different points in time by applying the BPI construction price index (DESTATIS, 2010b) and the VPI consumer price index (DESTATIS, 2012). The BPI and VPI development over the past $20 \mathrm{yr}$ can be seen in Fig. 7.

BPI shows periods of stagnation (1995 to 2003) and rapid growth (up to $8 \%$ p.a. - 2007). Overall, there is a positive linear trend that is extrapolated to 2020 . The increase of consumer prices in Germany since 2000 is nearly constant and the linear trend for this time span is extrapolated to 2020 . Consumer prices for Eastern Germany show a similar pattern from 1994 to 2000. From 1990 to 1993 there is a steep rise in consumer prices following the German reunification. This increase substantially exceeds the rise of building construction costs and thus results in a decrease of effective building

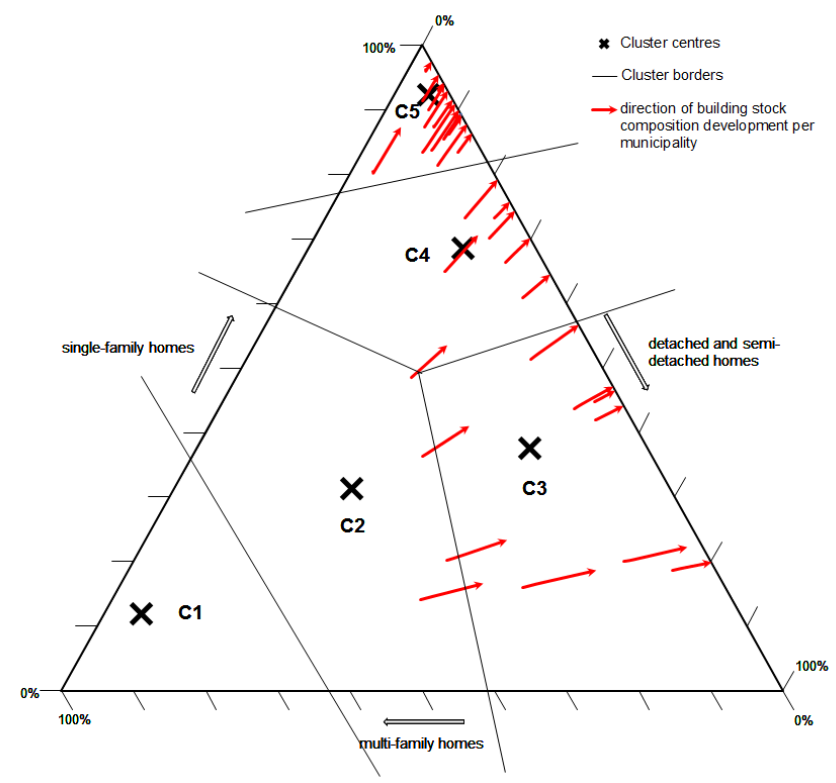

Fig. 8. Development of building type composition in the study area 1990 to 2020 .

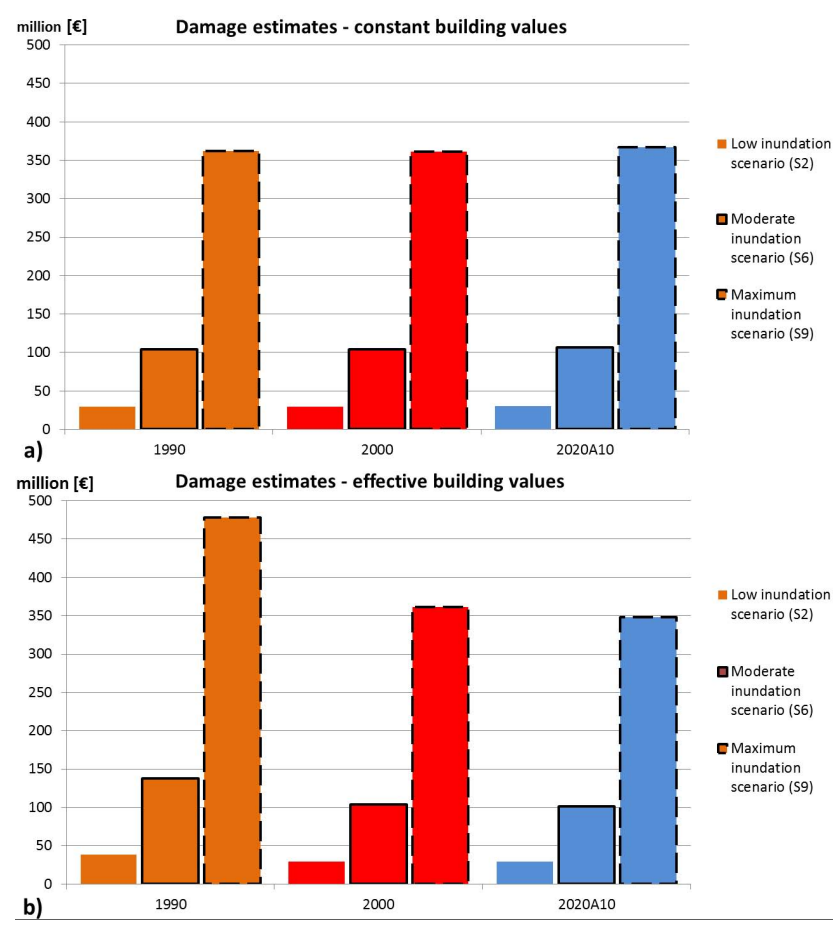

Fig. 9. Estimated damage using (a) constant building values and (b) effective building values for selected inundation scenarios.

values. Effective as well as constant asset values are used in the form of raster maps as input for flood damage modelling.

The composition of the building stock is closely related to land-use change patterns. Urban sprawl is the dominant process of residential development in the Mulde basin 
Table 3. Development of residential land-use 1990 to 2020.

\begin{tabular}{lllllll}
\hline Residential Land-Use & 1990 & \multirow{2}{*}{2000} & \multicolumn{2}{c}{2010} & \multicolumn{2}{c}{2020} \\
\cline { 4 - 7 } & & & B2 ${ }^{+}$ & $\mathrm{A}^{0}$ & \multirow{2}{*}{ B2 $^{+}$} & \multirow{2}{*}{ A1 $^{0}$} \\
\hline \% of total area & 7.9 & 8.4 & 8.5 & 8.7 & 8.7 & 9.1 \\
$\%$ of 2000 & 94.2 & 100 & 101.5 & 103.8 & 103.2 & 108.0 \\
\hline
\end{tabular}

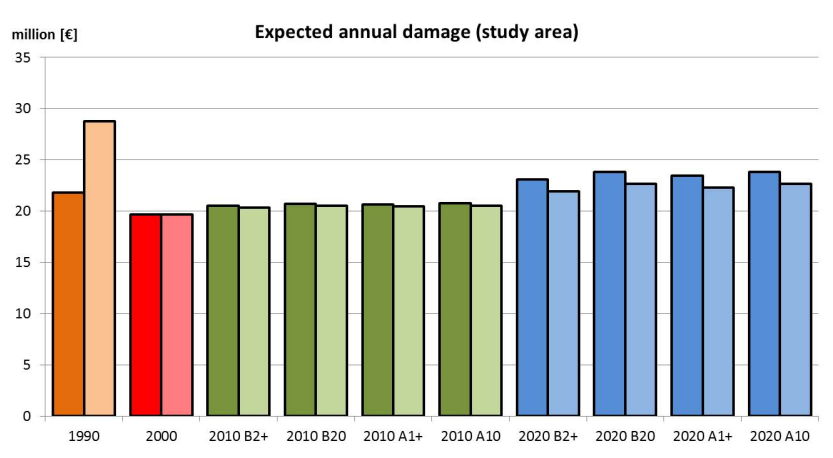

Fig. 10. Flood risk (EAD) development for the study area 1990 to 2020. Dark colours indicate the use of constant values; light colours the use of effective values.

(Hoymann, 2010). This is consistent as new buildings are nearly exclusively of the single-family home type. Figure 8 shows the development of building stock composition in the study area. Each axis of the diagram gives the share of the respective residential building type, summing up to $100 \%$ (in a clockwise direction). Every red arrow represents one municipality in the study area, stating the direction and magnitude of the development from 1990 to 2020. Cluster centres for all German municipalities for the year 2000 are marked by crosses named C1-C5. The building type clusters can be characterised as:

C1 dominated by multi-family homes

C2 mixed (high share of multi-family homes)

C3 mixed (high share of detached and semi-detached homes)

C4 mixed (high share of single-family homes)

C5 dominated by single-family homes

A clear cluster affiliation for each municipality in the study area at every point in time is performed by minimizing the distance to the next cluster centre.

For all municipalities, regardless of original cluster membership, the share of single-family homes rises while the percentage of multi-family homes drops. Shares of detached and semi-detached homes show a slight increase in most and a remarkable increase in some (C2, C3) municipalities.

\subsection{Flood damage and flood risk}

The maximum estimated flood damage for residential buildings in the study area for the most extreme inundation scenario (S9) is 366.6 million $€$ using constant values ( $\mathrm{A} 1^{0}$ land use scenario in 2020, Fig. 9a) and 477.8 million $€$ (1990, prices as of 2000) using effective values (Fig. 9b). Damage estimations for the (high probability) inundation scenario S2 are one order of magnitude smaller (see Fig. 9).

While the estimated damage for the study area varies by more than an order of magnitude, depending on the inundation scenario, the relative change of damage over time is nearly constant for all inundation scenarios (constant values, Fig. 9a). The picture is different when effective building values are used: While the changes from 2000 to $2020\left(\mathrm{~A} 1^{0}\right.$ scenario conditions) are relatively small, damage estimates for 1990 are more than $30 \%$ higher than for 2000 with only minor differences between scenarios. Other scenario conditions $\left(\mathrm{A}^{+}, \mathrm{B} 2^{0}, \mathrm{~B} 2^{+}\right)$result in similar differences of estimated damage from 2000 to 2020.

The integration of the risk curve over damage estimates for all return periods results in estimations of EAD. Changes in EAD with time (Fig. 10) show an increase from 2000 to 2020 for all scenarios and constant as well as effective values. EAD development from 1990 to 2000 shows decreasing risk for constant (from 21.8 million $€$ to 19.7 million $€$ ) as well as for effective values ( 28.8 million $€$ to 19.7 million $€)$. This huge decrease when using effective values can be attributed to the steep rise of general inflation after 1990 and should be seen as an exceptional economic situation in the historical context.

Different land-use scenarios result in maximum differences of EAD between scenarios of 0.2 million $€$ (or $1 \%$ ) for 2010 and 0.7 million $€$ (approximately $4 \%$ ) for 2020 .

A closer look at the results of the municipality level reveals that the spatial variability of risk in the study area is quite high. It becomes evident that the major cities of Dessau and Eilenburg contribute $2 / 3$ to the total EAD as of 2000. The share distribution shown in Fig. 11 is characteristic for all points in time, which is explained by relatively homogeneous land-use and building stock development.

Small to moderate events with recurrence intervals of up to $20 \mathrm{yr}$ dominate risk expectation, as exemplified in Fig. 12 for the year 2000. This result is in accordance with earlier studies by Merz and others (Merz, 2006; Merz et al., 2010a; Merz and Gocht, 2001). It is important to keep in mind that 


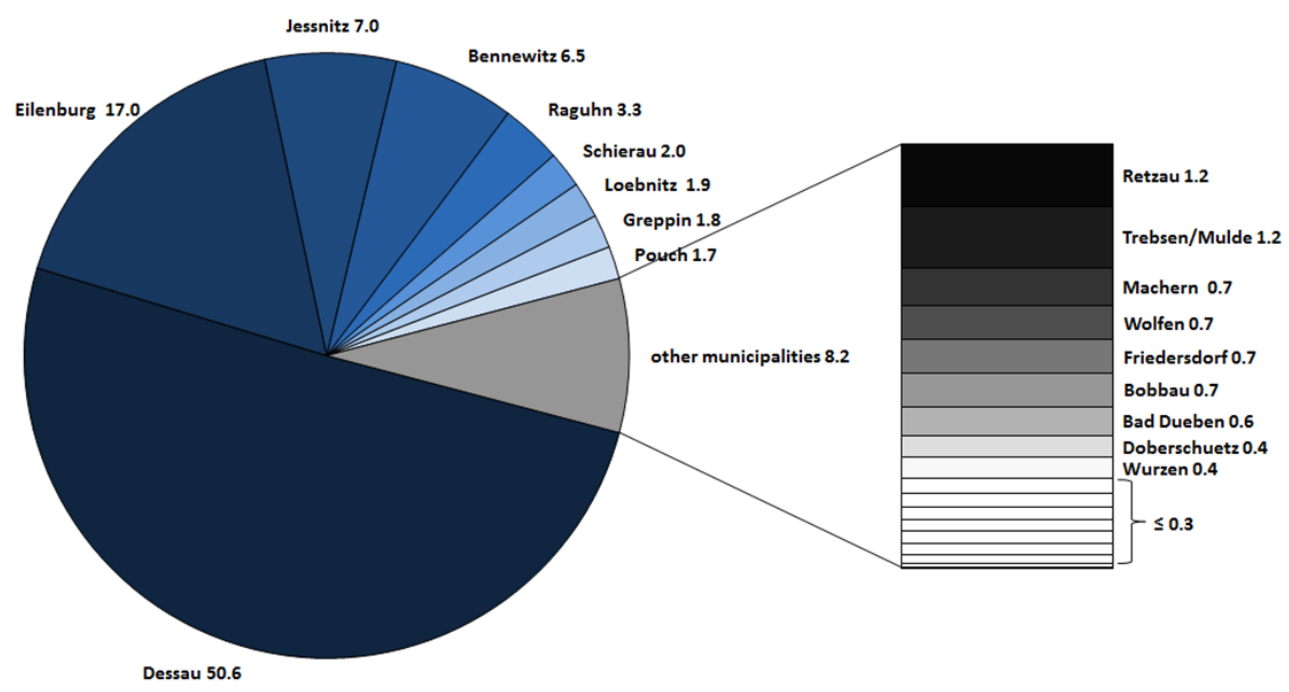

Fig. 11. Contribution of different municipalities to study area EAD as of 2000.

flood protection is omitted in this study. The insertion of protection targets would erase damage caused by floods smaller than the design flood and hence influence the contribution share of events of different magnitude.

On the municipality level, relative risk changes over time vary greatly. Small scale developments, e.g. in land-use change, have significant influence and can lead to strong changes in EAD. Still, the risk change over time in the entire study area is dominated by and hence very similar to the development in the large municipalities.

\subsection{Quantification of risk change drivers}

Estimating damage and risk in monetary values without adjusting them to a given reference year would give the reconstruction costs - the financial damage - at the time when the damage is realized or the risk is accounted for. But in this concept, inflation is not externalised and thus risk comparisons over time are biased. This can be avoided by using constant values (per unit of area). In this study, constant year 2000 values per $\mathrm{m}^{2}$ were used for all points in time. Nevertheless, construction price development can differ from general inflation and hence, an effective change of building values with time is possible. To consider the influence of these inherent value changes as a driver of flood risk, we adjusted year 2000 values to 1990, 2010 and 2020 prices by applying the BPI and correct the results for general inflation (VPI). Consequently, the monetary results (damage/risk estimations) are given in $€$ at the prices of the base year 2000. The effective value of residential buildings in the study area decreased rapidly after the introduction of the "Deutsche Mark" in Eastern Germany in 1990 due to special economic effects: The harmonisation of consumer prices in both parts of Germany resulted in high inflation rates in East- ern Germany until 1993. The increase of building construction prices was much smaller in these years. Since the mid1990 s, the volatility of the BPI was still higher than that of general inflation but both show similar trend behaviour (see Fig. 7).

Very few areas changed from residential use to other land-use types in the time frame of our study. All significant changes were settlement expansions, predominantly into prior agricultural areas. This expansion was a highly homogenous process. Demand and supply of living space changed abruptly in 1989/1990 in Eastern Germany and since then, single-family houses make up more than $90 \%$ of new residential buildings in the study area. As the FLEMOps+r damage model considers differences in relative damage due to building types, the relation between land-use increase and increase of (estimated) damage is not linear.

The moving window approach to derive gauge specific flood hazard and its change by applying extreme value analyses and the fact that no significant trends are detected for extreme discharges in the study area is reflected in the hazard specific risk estimates: There is no steady increase with time.

The separation of influences on overall risk change shows major differences in the contribution of the three drivers to risk increase (Table 4). Based only on the development of effective values, risk in 1990 is $132 \%$ of the risk in 2000 . The further decrease is small: Starting in 2000, the decrease is $1 \%$ to 2010 and $5 \%$ to 2020 for our test case.

Climate induced hazard change leads to changes in damage risk of $17 \%$ maximum from 2000 to 2020. But the hazard shows strong fluctuations. As stated before, climate change and flood hazard change analyses from earlier studies showed no or minor changes for the region and these findings are affirmed here. Hence, the influence of climate change on 


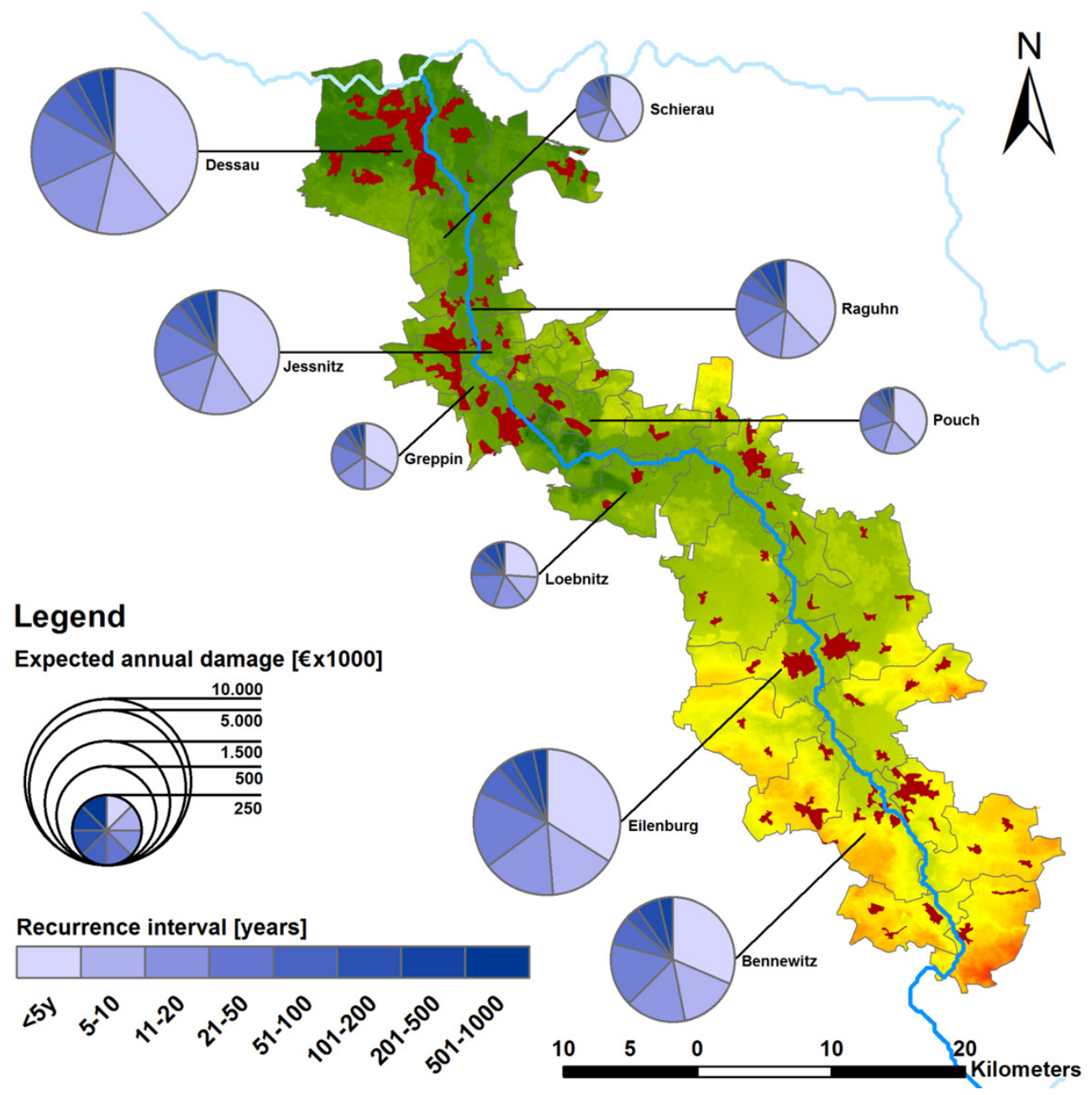

Fig. 12. Contribution of event magnitude to EAD in 2000 for the most affected municipalities.

risk development cannot be interpreted for this region, but the flood hazard fluctuations give an impression of the magnitude of the influence of climate - or better flooding - variability.

The third type of development considered in this analysis was changes in land use and building stock composition. With this parameter as single influence risk in 2000 is $20 \%$ higher than 1990 and increases by a maximum of $32 \%\left(\mathrm{Al}^{0}\right.$ scenario) from 2000 to 2020 . This parameter can be influenced by regional and national (land-use) policies. The maximum risk increase of $21 \%$ (constant values) or $15 \%$ (effective values) can be lowered by up to 4 percentage points (2000 to 2020) when applying strict regulations to the development of residential areas $\left({ }^{+}\right.$-scenarios).

\section{Conclusions}

In this study we established a flood risk chain from climate influences on meteorology over hydrological and hydraulic modelling to damage and risk estimations, using measured data and state-of-the-art modelling approaches. The results show high flood risk in the area and an increase of this risk for residential buildings from 2000 to 2020 . When using constant building values, a slight decrease of flood risk is found from 1990 to 2000 that can be attributed to a decrease in the flood hazard. Based on effective values, there is a distinct reduction of EAD for this time frame.

The spatial risk distribution and the risk contribution of events of different probability show that risk for the study area is dominated by the residential areas of the major cities. Frequent events with recurrence intervals up to approximately $50 \mathrm{yr}$ cause more than $80 \%$ of the annually expected damage.

Attribution of risk changes to single drivers showed that the expansion of residential areas is the main driver of flood risk in the study area. Consequently, the potential influence of local and regional land-use policies is substantial and could contribute significantly to short-term and/or mediumterm risk mitigation: As for land-use scenarios that assume 
Table 4. Overall risk change compared to single parameter risk change for the study area.

\begin{tabular}{|c|c|c|c|c|c|}
\hline \multirow[b]{2}{*}{$\begin{array}{l}\text { Year/ } \\
\text { Scenario }\end{array}$} & \multicolumn{5}{|c|}{ Expected annual damage } \\
\hline & Hazard & $\begin{array}{l}\text { Land use and } \\
\text { building type }\end{array}$ & $\begin{array}{l}\text { All } \\
\text { (constant values) }\end{array}$ & $\begin{array}{l}\text { Effective } \\
\text { building value }\end{array}$ & $\begin{array}{l}\text { All (effective building } \\
\text { value included) }\end{array}$ \\
\hline 1990 & $\begin{array}{l}21.897 .442 € \\
111 \%\end{array}$ & $\begin{array}{l}15.848 .608 € \\
80 \%\end{array}$ & $\begin{array}{l}21.788 .503 € \\
111 \%\end{array}$ & $\begin{array}{l}26.009 .414 € \\
132 \%\end{array}$ & $\begin{array}{l}28.781 .278 € \\
146 \%\end{array}$ \\
\hline 2000 & $\begin{array}{l}19.690 .098 € \\
100 \%\end{array}$ & $\begin{array}{l}19.690 .098 € \\
100 \%\end{array}$ & $\begin{array}{l}19.690 .098 € \\
100 \%\end{array}$ & $\begin{array}{l}19.690 .098 € \\
100 \%\end{array}$ & $\begin{array}{l}19.690 .098 € \\
100 \%\end{array}$ \\
\hline $2010 \mathrm{~A} 1^{0}$ & $\begin{array}{l}20.443 .715 € \\
104 \%\end{array}$ & $\begin{array}{l}23.074 .321 € \\
117 \%\end{array}$ & $\begin{array}{l}20.754 .312 € \\
105 \%\end{array}$ & $\begin{array}{l}19.467 .214 € \\
99 \%\end{array}$ & $\begin{array}{l}20.523 .674 € \\
104 \%\end{array}$ \\
\hline $2010 \mathrm{~A}^{+}{ }^{+}$ & $\begin{array}{l}20.443 .715 € \\
104 \%\end{array}$ & $\begin{array}{l}22.981 .878 € \\
117 \%\end{array}$ & $\begin{array}{l}20.673 .118 € \\
105 \%\end{array}$ & $\begin{array}{l}19.467 .214 € \\
99 \%\end{array}$ & $\begin{array}{l}20.443 .381 € \\
104 \%\end{array}$ \\
\hline $2010 \mathrm{~B} 2^{0}$ & $\begin{array}{l}20.443 .715 € \\
104 \%\end{array}$ & $\begin{array}{l}23.054 .057 € \\
117 \%\end{array}$ & $\begin{array}{l}20.734 .970 € \\
105 \%\end{array}$ & $\begin{array}{l}19.467 .214 € \\
99 \%\end{array}$ & $\begin{array}{l}20.504 .546 € \\
104 \%\end{array}$ \\
\hline $2010 \mathrm{~B}^{+}$ & $\begin{array}{l}20.443 .715 € \\
104 \%\end{array}$ & $\begin{array}{l}22.846 .038 € \\
116 \%\end{array}$ & $\begin{array}{l}20.550 .287 € \\
104 \%\end{array}$ & $\begin{array}{l}19.467 .214 € \\
99 \%\end{array}$ & $\begin{array}{l}20.321 .916 € \\
103 \%\end{array}$ \\
\hline $2020 \mathrm{~A} 1^{0}$ & $\begin{array}{l}23.113 .710 € \\
117 \%\end{array}$ & $\begin{array}{l}25.922 .105 € \\
132 \%\end{array}$ & $\begin{array}{l}23.841 .090 € \\
121 \%\end{array}$ & $\begin{array}{l}18.713 .324 € \\
95 \%\end{array}$ & $\begin{array}{l}22.658 .396 € \\
115 \%\end{array}$ \\
\hline $2020 \mathrm{~A}^{+}{ }^{+}$ & $\begin{array}{l}23.113 .710 € \\
117 \%\end{array}$ & $\begin{array}{l}25.453 .723 € \\
129 \%\end{array}$ & $\begin{array}{l}23.436 .873 € \\
119 \%\end{array}$ & $\begin{array}{l}18.713 .324 € \\
95 \%\end{array}$ & $\begin{array}{l}22.274 .231 € \\
113 \%\end{array}$ \\
\hline $2020 \mathrm{~B} 2^{0}$ & $\begin{array}{l}23.113 .710 € \\
117 \%\end{array}$ & $\begin{array}{l}25.901 .276 € \\
132 \%\end{array}$ & $\begin{array}{l}23.817 .529 € \\
121 \%\end{array}$ & $\begin{array}{l}18.713 .324 € \\
95 \%\end{array}$ & $\begin{array}{l}22.636 .004 € \\
115 \%\end{array}$ \\
\hline $2020 \mathrm{~B}^{+}$ & $\begin{array}{l}23.113 .710 € \\
117 \%\end{array}$ & $\begin{array}{l}25.051 .534 € \\
127 \%\end{array}$ & $\begin{array}{l}23.069 .287 € \\
117 \%\end{array}$ & $\begin{array}{l}18.713 .324 € \\
95 \%\end{array}$ & $\begin{array}{l}21.924 .880 € \\
111 \%\end{array}$ \\
\hline
\end{tabular}

strict land-use policies $\left({ }^{+}\right.$-scenarios), the risk increase is considerably limited.

Climate induced flood hazard change is also an important but not a dominant factor of risk change in the study area. However, for a detailed analysis of hazard change, the study period might be quite short, and in the long term, global warming might change the flood regime in northeastern Germany in a way not accounted for in our analysis.

The influence of effective value development must be interpreted with caution: The overall influence of effective value changes appears to be weak. Construction price and consumer price indexes show concurring trend behaviour since the mid-90s and differences can be explained by the higher volatility of construction prices as they are more influenced by economic cycles than general inflation. The distinct reduction of EAD from 1990 to 2000 is caused mainly by value changes. This is an effect of historically exceptional economic developments in Eastern Germany in the early 1990s. The benefit of using effective values in future research seems questionable, at least if damage (and building value) is defined as reconstruction costs, i.e. the cost approach is selected to value residential buildings. Using real estate market prices as building values, i.e. the sales comparison approach, might result in different recommendations.
Some more points should be accounted for in future research: Protection measures were not considered in this study due to a lack of data. Protection structures like dams reduce the influence of high-probability flood events on flood risk. This has implications for risk comparison. Flood hazard does not change evenly over time for the entire range of event probabilities (see Fig. 6). Relative risk change from time to time that considers the whole range of event probabilities is different from relative risk change when high probabilities are omitted. If available, such data should be included to make flood risk assessment more realistic. Official statistics will probably take a large step forward in data quality in terms of up-to-dateness and accuracy after the 2011 census in Germany. Current approaches and data sets (e.g. building stock) should be checked and updated accordingly. For the study period, our risk estimation concentrated on residential buildings as an indicator for flood risk. A comprehensive risk assessment should include all economic sectors. We used the best available data and models, but an ensemble approach would allow for better estimation of the inherent uncertainties of the model chain. Finally, expanding the approach to the macro-, i.e. national, scale would enable the calculation of trans-basin flood risk and hence the overall flood risk associated with large scale events. 
Acknowledgements. The survey was undertaken and partly financed under the framework of CEDIM - Center for Disaster Management and Risk Reduction Technology. This work is a contribution to the "Helmholtz Climate Initiative REKLIM" (Regional Climate Change), a joint research project of the Helmholtz Association of German research centres (HGF).

We gratefully thank Sören Haubrock and Mr. Dung-Viet Nguyen for their help in model coupling and the automatisation of the model chain. Mr. Janek Zimmer and Yeshewatesfa Hundecha supported us with climate data services and data processing.

Edited by: D. Keefer

Reviewed by: two anonymous referees

\section{References}

Apel, H., Thieken, A., Merz, B., and Blöschl, G.: A Probabilistic Modelling System for Assessing Flood Risks, Nat. Hazards, 38, 79-100, 2006.

Apel, H., Aronica, G., Kreibich, H., and Thieken, A.: Flood risk analyses-how detailed do we need to be?, Nat. Hazards, 49, 79-98, 2009.

Archer, D. R., Climent-Soler, D., and Holman, I. P.: Changes in discharge rise and fall rates applied to impact assessment of catchment land use, Hydrol. Res., 41, 13-26, 2010.

Barredo, J. I.: Normalised flood losses in Europe: 1970-2006, Nat. Hazards Earth Syst. Sci., 9, 97-104, doi:10.5194/nhess-997-2009, 2009.

Beurton, S. and Thieken, A. H.: Seasonality of floods in Germany, Hydrol. Sci. J.-J. Sci. Hydrol., 54, 62-76, 2009.

Blöschl, G., and Montanari, A.: Climate change impacts - throwing the dice?, Hydrol. Process., 24, 374-381, 2010.

Bouwer, L. M., Bubeck, P., and Aerts, J. C. J. H.: Changes in future flood risk due to climate and development in a Dutch polder area, Global Environ. Change, 20, 463-471, 2010.

Bronstert, A., Niehoff, D., and Burger, G.: Effects of climate and land-use change on storm runoff generation: present knowledge and modelling capabilities, Hydrol. Process., 16, 509-529, 2002.

Bundesanstalt für Gewässerkunde (BfG): Das Hochwasser der Elbe im Frühjahr 2006, Bericht BFG-1514, 43 pp., 2006.

De Roo, A., Schmuck, G., Perdigao, V., and Thielen, J.: The influence of historic land use changes and future planned land use scenarios on floods in the Oder catchment, Phys. Chem. Earth, 28, 1291-1300, 2003.

Deutsches Klimarechenzentrum (DKRZ): Climate Simulation with CLM, Scenario A1B run no.2, Data Stream 3: European region (CLM_A1B_2_D3). CLM regional climate model runs forced by the global IPCC scenario runs (archive.dkrz.de:/ut/k/k204095/prism/experiments/A1B_2), Creation date: 09/11/2006, 2006.

Deutsches Klimarechenzentrum (DKRZ): Climate Simulation with CLM, Climate of the 20th Century run no.2, Data Stream 3: European region (CLM_C20_2_D3). CLM regional climate model runs forced by the global IPCC scenario runs (archive.dkrz.de:/ut/k/k204095/prism/experiments/C20_2), Creation date: 29/01/2007, 2007.

Duan, Q. Y., Sorooshian, S., and Gupta, V.: Effective and efficient global optimization for conceptual rainfall-runoff models, Water
Resour. Res., 28, 1015-1031, 1992.

Duan, Q. Y., Gupta, V. K., and Sorooshian, S.: Shuffled complex evolution approach for effective and efficient global minimization, J. Optim. Theory Appl., 76, 501-521, 1993.

Duan, Q. Y., Sorooshian, S., and Gupta, V. K.: Optimal use of the SCE-UA global optimization method for calibrating watershed models, J. Hydrol., 158, 265-284, 1994.

Elmer, F., Thieken, A. H., Pech, I., and Kreibich, H.: Influence of flood frequency on residential building losses, Nat. Hazards Earth Syst. Sci., 10, 2145-2159, doi:10.5194/nhess-10-21452010, 2010.

Engel, H.: The flood event 2002 in the Elbe river basin. Causes of the flood, its course, statistical assessment and flood damages, Houille Blanche, 6, 33-36, 2004.

Feyen, L., Barredo, J. I., and Dankers, R.: Implications of global warming and urban land use change on flooding in Europe, in: Water and Urban Development Paradigms - Towards an Integration of Engineering, Design and Management Approaches, edited by: Feyen, J., Shannon, K., and Neville, M., Crc PressTaylor \& Francis Group, Boca Raton, 217-225, 2009.

Graham, D. J. and Midgley N. G.: Graphical representation of particle shape using triangular diagrams: an Excel spreadsheet method, Earth Surf. Proc. Landf., 25, 1473-1477, 2000.

Haase, D., Weichel, T. and Volk, M.: Approaches towards the analysis and assessment of the disastrous floods in Germany in August 2002 and consequences for land use and retention areas, edited by: Vaishar, A., Zapletalova, J., and Munzar, J.: Regional Geography and its Applications, Proceedings of the 5th Moravian Geographical Conference CONGEO'03, 51-59, 2003.

Hall, J. W., Evans, E. P., Penning-Rowsell, E. C., Sayers, P. B., Thorne, C. R., and Saul, A. J.: Quantified scenarios analysis of drivers and impacts of changing flood risk in England and Wales: 2030-2100, Global Environ. Change Part B: Environmental Hazards, 5, 51-65, 2003.

Hartje, V., Ansmann, T., Blazejczak, J., Gömann, H., Gornig, M., Grossmann, M., Hillenbrand, T., Hoymann, J., Kreins, P., Markewitz, P., Mutafoglu, K., Richmann, A., Sartorius, C., Schulz, E., Vögele, S., and Walz, R.: Regionalisierung der Szenarioanalyse (der Antriebskräfte und des Nutzungsdruckes) des globalen Wandels für die Wasserwirtschaft, Schlussbericht zum BMBFVorhaben GLOWA-Elbe II: Wirkungen des globalen Wandels auf den Wasserkreislauf im Elbegebiet - Risiken und Optionen, Kapitel 2, 170 pp., 2008.

Hattermann, F. F.: Integrated Modelling of Global Change Impacts in the German Elbe River Basin, doctor rerum naturalium (Dr. rer. nat.), Mathematisch-Naturwissenschaftliche Fakultät, Universität Potsdam, Potsdam, 218 pp., 2005.

Hilferink, M. and Rietveld, P.: Land Use Scanner: an integrated GIS-based model for long term projections of land use in urban and rural areas, Tinbergen Institute discussion paper TI 98-108/3, TI 98, 22, 1998.

Horritt, M. S. and Bates, P. D.: Predicting floodplain inundation: raster-based modeling versus finite element approach, Hydrol. Process. 15, 825-842, 2001.

Horritt, M. S. and Bates, P. D.: Evaluation of 1D and 2D numerical models for predicting river flood inundation, J. Hydrol., 268, 8799, 2002.

Hoymann, J.: Land Use Scanner, GIS Business, 4, 34-37, 2008. 
Hoymann, J.: Spatial allocation of future residential land use in the Elbe River Basin, Environ. Plann. B, 37, 911-928, 2010.

Hoymann, J.: Accelerating urban sprawl in depopulating regions: a scenario analysis for the Elbe River Basin, Reg. Environ. Change, 11, 73-86, 2011.

International Commission for the Protection of the Rhine (ICPR): Atlas of flood danger and potential damage due to extreme floods of the Rhine, edited by: ICPR, Koblenz, 2001.

Intergovernmental Panel on Climate Change (IPCC): Summary for Policymakers: Emissions Scenarios, IPCC SPECIAL REPORT, 2000.

Keil, M., Kiefl, R., and Strunz, G.: CORINE Land Cover 2000 - Europaweit harmonisierte Aktualisierung der Landnutzungsdaten für Deutschland, Deutsches Zentrum für Luft- und Raumfahrt e.V. Deutsches Fernerkundungsdatenzentrum, Oberpfaffenhofen, Abschlussbericht zum F+E Vorhaben UBA FKZ 20112 209 UBA - FB 000 826, 83 pp., 2005.

Kleist, L., Thieken, A. H., Köhler, P., Müller, M., Seifert, I., Borst, D., and Werner, U.: Estimation of the regional stock of residential buildings as a basis for a comparative risk assessment in Germany, Nat. Hazards Earth Syst. Sci., 6, 541-552, doi:10.5194/nhess-6-541-2006, 2006.

Kreibich, H., and Thieken, A. H.: Assessment of damage caused by high groundwater inundation, Water Resour. Res., 44, W09409, 2008.

Krysanova, V., Muller-Wohlfeil, D. I., and Becker, A.: Development and test of a spatially distributed hydrological water quality model for mesoscale watersheds, Ecol. Model., 106, 261-289, 1998.

Krysanova, V., Wechsung, F., Arnold, J. G., Srinivasan, R., and Williams, J.: SWIM (Soil and Water Integrated Model), User Manual, 239 pp., 2000.

Kundzewicz, Z. W., Ulbrich, U., brücher, T., Graczyk, D., Krüger, A., Leckebusch, G. C., Menzel, L., Piñskwar, I., Radziejewski, M., and Szwed, M.: Summer Floods in Central Europe - Climate Change Track?, Nat. Hazards, 36, 165-189, 2005.

Landesamt für Umwelt (LuG): Das August-Hochwasser 2002 im Muldegebiet - eine meteorologisch-hydrologische Analyse, Sächsisches Landesamt für Umwelt, Landwirtschaft und Geologie, Dresden, 172 pp., 2009.

Merz, B.: Hochwasserrisiken. Möglichkeiten und Grenzen der Risikoabschätzung, E. Schweizerbart'sche Verlagsbuchhandlung, Stuttgart, 334 pp., 2006.

Merz, B. and Gocht, M.: Risikoanalyse Seckach/Kirnau. Teil II: Ermittlung von Schadenpotenzialen. Nutzen-Kosten-Analyse Deutsches GeoForschungsZentrum Potsdam, 87 pp., 2001.

Merz, B., Hall, J., Disse, M., and Schumann, A.: Fluvial flood risk management in a changing world, Nat. Hazards Earth Syst. Sci., 10, 509-527, doi:10.5194/nhess-10-509-2010, 2010.

Merz, B., Kreibich, H., Schwarze, R., and Thieken, A.: Review article "Assessment of economic flood damage", Nat. Hazards Earth Syst. Sci., 10, 1697-1724, doi:10.5194/nhess-10-16972010, 2010.

Merz, R. and Bloschl, G.: A regional analysis of event runoff coefficients with respect to climate and catchment characteristics in Austria, Water Resour. Res., 45, W01405, 2009.

Munich Re: Flooding and insurance. Munich Re Group, Munich, 79 pp., 1997.
Munich Re: TOPICSgeo - Annual Review: natural catastrophes 2003, Munich Re Group, Munich, 52 pp., 2004.

Nash, J. E. and Sutcliffe, J. V.: River flow forecasting through conceptual models part I - A discussion of principles, J. Hydrol., 10, 282-290, 1970.

Orr, H. G. and Carling, P. A.: Hydro-climatic and land use changes in the river lune catchment, North West England, implications for catchment management, River Res. Appl., 22, 239-255, 2006.

Österle, H., Gerstengarbe, F.-W., and Werner, P.C.: Ein neuer meteorologischer Datensatz für Deutschland, 1951-2003 Potsdam Institut für Klimafolgenforschung e.V., Potsdam, 3 pp., 2006.

Petrow, T. and Merz, B.: Trends in flood magnitude, frequency and seasonality in Germany in the period 1951-2002, J. Hydrol., 371, 129-141, 2009a.

Petrow, T., Zimmer, J., and Merz, B.: Changes in the flood hazard in Germany through changing frequency and persistence of circulation patterns, Nat. Hazards Earth Syst. Sci., 9, 1409-1423, doi:10.5194/nhess-9-1409-2009, 2009b.

Piani, C., Haerter, J., and Coppola, E.: Statistical bias correction for daily precipitation in regional climate models over Europe, Theor. Appl. Climatol., 99, 187-192, 2010.

Prudhomme, C., Wilby, R. L., Crooks, S., Kay, A. L., and Reynard, N. S.: Scenario-neutral approach to climate change impact studies: Application to flood risk, J. Hydrol., 390, 198-209, 2010.

Schotten, K., Goetgeluk, R., Hilferink, M., Rietveld, P., and Scholten, H.: Residential Construction, Land Use and the Environment, Simulations for the Netherlands Using a GIS-Based Land Use Model, Environ. Model. Assess., 6, 133-143, 2001.

Statistische Ämter des Bundes und der Länder (DESTATIS): Baufertigstellungen: Errichtung neuer Wohngebäude (https:// www-genesis.destatis.de/), last access: 20 May 2010, 2010a.

Statistisches Bundesamt (DESTATIS): Preise. Preisindizes für die Bauwirtschaft - Februar 2010, Fachserie 17, Reihe 4, Wiesbaden, 35 pp., 2010 b.

Statistisches Bundesamt (DESTATIS): Preise. Verbraucherpreisindex für Deutschland - Lange Reihen ab 1948 - Dezember 2011, Wiesbaden, 19 pp., 2012.

te Linde, A. H., Bubeck, P., Dekkers, J. E. C., de Moel, H., and Aerts, J. C. J. H.: Future flood risk estimates along the river Rhine, Nat. Hazards Earth Syst. Sci., 11, 459-473, doi:10.5194/nhess-11-459-2011, 2011.

Thieken, A. H., Müller, M., Kreibich, H., and Merz, B.: Flood damage and influencing factors: New insights from the August 2002 flood in Germany, Water Resour. Res., 41, W12430, 2005.

Thieken, A. H., Müller, M., Kleist, L., Seifert, I., Borst, D., and Werner, U.: Regionalisation of asset values for risk analyses, Nat. Hazards Earth Syst. Sci., 6, 167-178, doi:10.5194/nhess6-167-2006, 2006.

Thieken, A. H., Olschewski, A., Kreibich, H., Kobsch, S., and Merz, B.: Development and evaluation of FLEMOps - a new Flood Loss Estimation MOdel for the private sector, in: Flood Recovery, Innovation and Response, edited by: Proverbs, D., Brebbia, C. A., and PenningRowsell, E., Wit Transactions on Ecology and the Environment, Wit Press, Southampton, 315324, 2008.

US Army Corps of Engineers (USACE): HEC-RAS River Analysis System User's Manual, US Army Corps of Engineers, Davis, USA Version 4.1, 790 pp., 2010. 
Veijalainen, N., Lotsari, E., Alho, P., Vehviläinen, B., and Käyhkö, J.: National scale assessment of climate change impacts on flooding in Finland, J. Hydrol., 391, 333-350, 2010.

Wood, E. F. and Rodríguez-Iturbe, I.: Bayesian Approach to Analyzing Uncertainty Among Flood Frequency Models, Water Resour. Res., 11, 839-843, 1975.
Wünsch, A., Herrmann, U., Kreibich, H., and Thieken, A.: The Role of Disaggregation of Asset Values in Flood Loss Estimation: A Comparison of Different Modeling Approaches at the Mulde River, Germany, Environ. Manage., 44, 524-541, 2009.

Yang, D., Ishida, S., Goodison, B. E., and Gunther, T.: Bias correction of daily precipitation measurements for Greenland, J. Geophys. Res., 104, 6171-6181, 1999. 